\title{
Production potential and economics of wheat, Triticum aestivum as influenced by different planting methods in Punjab, India
}

\section{Balkaran Singh Sandhu*, Nirmaljit Singh Dhaliwal and Gurmail Singh Sandhu}

Krishi Vigyan Kendra, Sri Muktsar Sahib-152026 (Punjab), INDIA

*Corresponding author. E-mail: balkaransandhu@gmail.com

Received: August 18, 2015; Revised received: February 9, 2016; Accepted: May 13, 2016

Abstract: The burning of rice straw after rice harvest in the Rice-Wheat System can be overcome by direct seeding of wheat by in standing and loose rice straw. To find out the most appropriate method of wheat sowing after rice crop in Sri Muktsar Sahib district, a field experiment was conducted with five different sowing methods including zero tillage and happy seeder. Among the different planting methods maximum grain yield was obtained with the conventional (52.26 q/ha) and happy seeder without loose straw (51.93 $\mathrm{q} / \mathrm{ha}$ ) planting method as compared to happy seeder with loose straw (50.83 q/ha), zero tillage (49.80 q/ha) and conventional method with mulching (49.66 q/ha). However, the benefit-cost ratio was higher by happy seeder with $(2.38: 1)$ and without loose straw $(2.35: 1)$ as compared to zero tillage method (2.31:1) and conventional (2.14:1). Higher B:C ratio with happy seeder was also due to its lesser cost of cultivation as compared to conventional method of sowing. The higher net return obtained from happy seeder with and without loose straw Rs. 50104 and Rs. 51019/ha respectively as compared zero tillage method (Rs 48663/ ha) and conventional tillage method (Rs. 49856/ha). Although the grain yield under conventional method of sowing was higher but it failed to produce higher net return and B:C ratio. Happy Seeder technology is a time savings, good option against burning of rice residue in Punjab.

Keywords: B:C ratio, Happy seeder, Planting method, Wheat, Yield

\section{INTRODUCTION}

Rice (Oryza sativa L.) - wheat (Triticum aestivum L.) is the major cropping system in Indo-Gangetic Plains of South Asia. However, productivity of rice and wheat has stagnated and declined owing to climate change and reduced soil productivity, posing a serious threat to the sustainability of the rice-wheat cropping system (Ladha et al., 2009). Low levels of soil organic matter, over mining from soils and burning of crop residues are some of the major reasons for declining rice-wheat productivity in the region (Singh and Sidhu, 2014). Hence the major challenge is to increase the productivity to meet the growing food demand without adverse environmental impact. Combine harvesters are commonly used for harvesting of rice-wheat in north-western India but in these combine harvested areas, managing heavy loads of rice residues is the major issue. Farmers generally burn rice residue prior to wheat sowing as the cheap and easy option for residue management, but burning leads to losses of soil organic matter and nutrients (especially N, P, K, S and $\mathrm{C}$ ), and creates environmental pollution (Singh et al., 2007; Hira, 2009). Potential solutions for these issues include a shift from conventional tillage to conservation agriculture based crop management system (Saharawat et al, 2010; Jat et al, 2012; Gathala et al, 2013). Direct planting with zero tillage technology is one such practice that potentially addresses the issues of labor, water, soil health etc (Malik et al 2005; Gupta and Sayre, 2007; Jat et al, 2009; Gathala et al, 2011; Jat et $a l, 2013)$. Similarly happy seeder is a planter capable of direct drilling in the fields with surface retention of residues and without any soil disturbance (Gathala et al., 2009). The residue on the soil surface reduce evaporative losses, retain the soil moisture and temperature, as well as canopy temperature (Jat et al, 2009) and help to counter terminal heat effects (Gupta et al, 2010). Residue retention also leads to significant improvement in $\mathrm{C}$ sustainability index (Alvarez and Steinbach 2009; Jat et al, 2011; Jat 2013). A lot of work on the effect of tillage conditions on agronomic parameter is available in literature (Khuhro et al., 2002; Erdem et al., 2006; Azam et al., 2008) but information regarding their effect on insect pests is not available. The pest scenario of wheat also changed with different tillage practice. With the adoption of no tillage practice, new pest like pink stem borer, Sesamia inferens has emerged in Northern India (Anonymous, 2008). However, conservation technologies in wheat are of limited adoption in Punjab, due to difficulty in sowing operation as compared to conventional tillage method. Keeping these points in view an experimental trial was conducted to evaluate the feasibility of direct-drilling of wheat in the presence of heavy loads of rice residue using the zero tillage and happy seeder 
and the effects of tillage and residue management methods on wheat crop productivity and pest incidence in south-western part of Punjab. Objective of the study was to work out the comparative returns in different tillage practices.

\section{MATERIALS AND METHODS}

A field experiment was conducted during rabi 2014-15 at Krishi Vigyan Kendra, Sri Muktsar Sahib (Punjab), to find out the most appropriate method of wheat sowing after rice crop in Sri Muktsar Sahib district of Punjab state. The geographical location of the experimental site was 7430'29" East longitude, 30²6’44" North latitude. The area is characterized by semi-arid type of climate with hot and dry early summers from AprilJune followed by hot and humid period during JulySeptember and cold winters during December-January. The mean maximum temperatures was $29.7{ }^{\circ} \mathrm{C}$ and mean minimum temperatures was $15.6{ }^{\circ} \mathrm{C}$. The annual rainfall of the area is $996 \mathrm{~mm}$, most of which is received during July to September (Anonymous, 2014a). The soil was sandy loam, slightly alkaline in reaction $(\mathrm{pH} 7.75)$, high $\mathrm{EC}(0.930 \mathrm{dS} / \mathrm{m})$, low in available organic carbon $(0.24 \%)$, medium in available phosphorus (17 kg/ha) and high in available potassium $(720 \mathrm{~kg} / \mathrm{ha})$. The experiment was laid out in randomized complete block design with three replications. The area is major rice growing pockets of Punjab. In the area combine harvesting of rice and wheat is now a common practice leaving large amount of residues in the fields. Farmers generally burn rice residues because as they felt that it interferes with tillage and seeding operations for the succeeding crops and it has no much economical use. To overcome this problem a field experiment was conducted with five different sowing methods viz. $\mathrm{T}_{1}$-conventional method, $\mathrm{T}_{2}$ conventional method + mulching, $\mathrm{T}_{3}$-happy seeder with loose straw, $\mathrm{T}_{4}$-happy seeder without loose straw and $\mathrm{T}_{5}$-zero tillage. In $\mathrm{t}_{1}$ after combine harvesting the crop residue was removed and field was disc harrowed twice, followed by planking and another ploughing with a tractor drawn cultivator followed by planking. In $t_{2}$ crop was sown after conventional tillage and paddy straw mulch was uniformly spread over the field. In $\mathrm{T}_{3}$ after combine harvesting of rice crop, the loose straw of the crop were uniformly distributed to the whole field and sowing is done with the help of happy seeder. In $t_{4}$ after combine harvesting of rice crop, the loose straw of the crop were removed and sowing is done with the help of happy seeder. In $\mathrm{T}_{5}$ the loose straw of the crop were removed and sowing is done with the help of happy zero tillage drill. The most predominant wheat variety HD 2967 was sown as per recommended agronomic practices (Anonymous, 2014b). Nitrogen, phosphorus and potassium were applied through urea, single superphosphate and muriate of potash, respectively. The crop was sown on first week of November with $100 \mathrm{~kg} /$ ha seed rate. The observations on plant height, yield and yield attributes (effective tillers $/ \mathrm{m}^{2}$, grains/ear and ear length) were recorded at maturity. The incidence of pink stem borer was recorded from each plot separately and percent incidence was calculated. Data on grain and straw yield of each crop was recorded and statistically analyzed. The cost of cultivation of each method was worked out and net return of sowing method was calculated on prevailing market prices. The benefit-cost ratio of each sowing method was also calculated.

\section{RESULTS AND DISCUSSION}

Growth and yield: All the different planting methods failed to produce any significant effect on the plant height and ear length of the wheat crop (Table 1). However, the effective tillers per square meter were significantly higher among the planting method of happy seeder without loose straw (440.3), which was statistically at par with conventional method (439.1) and happy seeder with loose straw (430.4) treatment. The lower effective tillers were obtained with zero tillage (403.6) and conventional method with mulching (422.2) treatment. The number of grains per ear was significantly superior in conventional method (60.54) which was statistically at par with happy seeder without loose straw(60.48) and happy seeder with loose straw planting method (59.84) but significantly differ with zero tillage (59.39) and conventional method with mulching (59.63) planting method. Whereas, the 1000 grain weight was also significantly higher with the both happy seeder treatment and conventional method with mulching treatment from the treatment zero tillage and conventional method (Table 1).

Among the different planting methods maximum grain yield was obtained with the conventional method $(52.26 \mathrm{q} / \mathrm{ha})$ planting method and happy seeder without loose straw planting method (51.93 q/ha) which was significantly higher from happy seeder with loose straw $(50.83 \mathrm{q} / \mathrm{ha})$ and zero tillage $(49.80 \mathrm{q} / \mathrm{ha})$. Lowest grain yield was obtained with the conventional method with mulching (49.66 q/ha) planting method. The result confirms the findings of Singh el al., 2013, who reported that the wheat crop shown with happy seeder gave comparative higher yield. The yield by happy seeder without loose straw was higher due to higher effective tiller per square meter and higher number of grains per ear length. However as we discuss about the straw yield, it was also higher with conventional method $(83.5 \mathrm{q} / \mathrm{ha})$ planting method and happy seeder without loose straw planting method $(82.47 \mathrm{q} / \mathrm{ha})$ which was significantly higher from all other different planting methods. These results were in agreement with the finding of Singh and Sidhu, 2014. They reported that happy seeder is better option to manage crop residue in rice-wheat cropping system as crop residue contain significant quantities of plant nutrients; their continuous application will have positive effect on fertilizer management in rice-wheat system. In present study, though the yield obtained by happy seeder was significantly at par with conventional tillage, 
Table 1. Growth and yield of wheat crop and incidence pink stem borer as influenced by different planting methods.

\begin{tabular}{|c|c|c|c|c|c|c|c|c|}
\hline Planting method & $\begin{array}{l}\text { Plant } \\
\text { height } \\
\text { (cm) }\end{array}$ & $\begin{array}{l}\text { Effective } \\
\text { Tillers } / \mathbf{m}^{2}\end{array}$ & $\begin{array}{l}\text { Ear } \\
\text { length } \\
\text { (cm) }\end{array}$ & $\begin{array}{l}\text { No. of } \\
\text { grains/ } \\
\text { ear }\end{array}$ & $\begin{array}{l}1000 \\
\text { grain } \\
\text { weight }\end{array}$ & $\begin{array}{l}\text { Grain } \\
\text { yield (q/ } \\
\text { ha) }\end{array}$ & $\begin{array}{l}\text { Straw } \\
\text { yield }(q / \\
\text { ha) }\end{array}$ & $\begin{array}{l}\text { Incidence of } \\
\text { pink stem } \\
\text { borer }(\%)\end{array}$ \\
\hline Conventional method & 90.15 & 439.1 & 10.965 & 60.54 & 42.07 & 52.26 & 83.5 & 0.05 \\
\hline $\begin{array}{l}\text { Conventional method } \\
+ \\
\text { Mulching }\end{array}$ & 88.7 & 422.2 & 10.44 & 59.63 & 42.74 & 49.66 & 78.8 & 0.10 \\
\hline $\begin{array}{l}\text { Happy seeder with } \\
\text { loose straw }\end{array}$ & 89 & 430.4 & 10.7 & 59.84 & 43 & 50.83 & 80.25 & 0.25 \\
\hline $\begin{array}{l}\text { Happy seeder with- } \\
\text { out loose straw }\end{array}$ & 88.715 & 440.3 & 10.85 & 60.48 & 42.89 & 51.93 & 82.47 & 0.15 \\
\hline Zero tillage & 88.6 & 403.6 & 10.3 & 59.39 & 42.46 & 49.80 & 78.58 & 0.10 \\
\hline $\mathrm{CD}(\mathrm{p}=0.05)$ & NS & 14.5 & NS & 0.70 & 0.5 & 1.12 & 2.0 & \\
\hline
\end{tabular}

Table 2. Economics of wheat crop as influenced by different planting methods.

\begin{tabular}{llllll}
\hline Planting method & $\begin{array}{l}\text { Yield } \\
(\mathbf{q} / \mathbf{h a})\end{array}$ & $\begin{array}{l}\text { Input Cost } \\
\text { (Rs) }\end{array}$ & $\begin{array}{l}\text { Gross return } \\
\text { (Rs) }\end{array}$ & $\begin{array}{l}\text { Net Return } \\
\text { (Rs) }\end{array}$ & $\begin{array}{l}\text { B:C } \\
\text { ratio }\end{array}$ \\
\hline Conventional method & 52.26 & 23307 & 73164 & 49856 & $2.14: 1$ \\
Conventional method + Mulching & 49.66 & 24432 & 69524 & 45091 & $1.85: 1$ \\
Happy seeder with loose straw & 50.83 & 21057 & 71162 & 50104 & $2.38: 1$ \\
Happy seeder without loose straw & 51.93 & 21682 & 72702 & 51019 & $2.35: 1$ \\
Zero tillage & 49.8 & 21057 & 69720 & 48663 & $2.31: 1$ \\
\hline
\end{tabular}

but in the long run the yield may increase in case of happy seeder due to above mentioned reason.

Relative incidence of pink stem borer: The pest appears sporadically in rice wheat cropping system under Punjab conditions. The incidence of this pest was observed during rabi 2014-15 and data presented in Table 1 . The pest incidence was low and it varied from $0.05-0.25$ per cent in different plots. The incidence was lowest in conventional method $(0.05 \%)$ followed by conventional method + mulching and zero tillage $(0.10 \%$ each $)$, happy seeder without loose straw $(0.15$ $\%)$ and highest in happy seeder with loose straw $(0.25$ $\%)$. This may be due to carry over of the pest from late infestation in paddy/basmati. In conventional tillage the life cycle of the pest is disturbed, whereas in other methods of wheat cultivation the pest remained in the straw and under favorable conditions population build quickly. Earlier workers also reported higher incidence of pink stem borer in zero tillage than conventional tillage in wheat crop (Razzaq et al., 1997; Singh, 2012). This was attributed to higher number of infested stubbles in no tillage fields (Razzaq et al., 1997). The pink stem borer incidence was also observed in conventional tillage which may be due to the reason that conventional tillage didn't completely destroy the rice stubbles and pest remained in the field even after ploughing several times.

Economics and benefit: cost ratio: Among the entire different planting methods the maximum gross return was obtained with the conventional method (Rs. 73164) treatment followed by happy seeder without loose straw planting method (Rs. 72702) followed by happy seeder with loose straw (Rs. 71162) and zero tillage (Rs. 69720). Gross returns among this planting method were higher due to higher grain yield obtained. Lowest gross return was obtained with the conventional method with mulching (Rs. 69524) planting method. Whereas, the net return was maximum in happy seeder without loose straw planting method (Rs. 51019) and happy seeder with loose straw (Rs. 50104) from the conventional (Rs. 49856) and zero tillage methods (Rs. 48663). Higher net return with happy seeder was due to its lesser cost of cultivation (Rs. 21057) as compared to conventional method of sowing (Rs. 23307). Lowest net return was also obtained with the conventional method with mulching (Rs. 69524) planting method. However, the benefit cost ratio was also higher with happy seeder with loose straw $(2.38: 1)$ and happy seeder without loose straw $(2.35: 1)$ as compared to conventional method (2.14:1) and conventional method with mulching $(1.85: 1)$. Higher $\mathrm{B}: \mathrm{C}$ ratio with happy seeder was also due to its lesser cost of cultivation as compared to conventional method of sowing. Benefit cost ratio of zero tillage method $(2.35: 1)$ of sowing was also higher from the conventional method $(2.14: 1)$. Due to the lesser cost of cultivation in zero tillage method the $\mathrm{B}: \mathrm{C}$ ratio was higher as compared to conventional method of sowing. Tripathi et al. (2013) also confirms the similar findings that zero tillage method of wheat sowings gave higher economics as compared to conventional method.

\section{Conclusion}

Tillage is one the main crop production operation and major contributor to the total cost of production. Residue burning is a part of the 'rice-wheat cropping system' that is the dominant cropping system in Punjab. Happy Seeder technology is a good option against burning of rice residue. This technology is also time savings because the Happy Seeder can be brought into the field immediately after the rice harvest and is environment friendly. Among the different planting methods 
maximum grain yield was obtained with the conventional and happy seeder without loose straw as compared to happy seeder with loose straw, zero tillage and conventional method with mulching. whereas, higher $\mathrm{B}: \mathrm{C}$ ratio was obtained by happy seeder with and without loose straw as compared to zero tillage method and conventional due to its lesser cost of cultivation as compared to conventional method of sowing. Thus happy seeder can play an important role in retaining soil and environmental health in Punjab.

\section{REFERENCES}

Alvarez, R., and Steinbach, H.S. (2009). A review of the effects of tillage systems on some soil physical properties, water content, nitrate availability and crops yield in the Argentine Pampas. Soil Tillage Research, 104: 1-15.

Anonymous (2008). Wheat crop health newsletter. Directorate of Wheat Research, Karnal. 14(2):p 1.

Anonymous (2014a). Report of Annual progress report of Krishi Vigyan Kendra, Sri Muktsar Sahib for the year 2014-15. p 5.

Anonymous (2014b). Package and practices for cultivation of rabi crops. Punjab Agricultural University, Ludhiana.

Azam, M.G., Zoebisch, A.M. and Wickramarachchi, S.K. (2008). Effects of cropping systems on selected soil structural properties and crop yields in Lam Phra Phloeng watershed - Northeast Thailand. Journal of Agronomy, 7:56-62.

Erdem, G., Yildirim, S. and Seven, I. (2006). The effect of soil tillage systems on wheat growth and yield in the dry land region of Turkey. Journal of Applied Science, 6:2408-2413.

Gathala, M. K., Kumar, V., Sharma, P. C., Saharawat, Y. S., Sharma, P. K., Jat, H. S., Singh, M., Kumar, A., Jat, M.L., Humphreys, E., Sharma, D. K., Sharma, S. and Ladha, J. K. (2009). Optimizing intensive cereal-based cropping systems addressing current and future drivers of agricultural change in the northwestern Indo-Gangetic plains of India. Agriculture Ecosystem and Environment, 177:85-97.

Gathala, M.K. Ladha, J.K., Kumar, V., Saharawat, Y.S., Kumar, V., Sharma, P.K., Sharma, S., Pathak, H. (2011). Tillage and crop establishment affects sustainability of South Asian rice-wheat system. Agronomy Journal, 103: 961-971.

Gathala, M.K., Kumar, V., Sharma, P.C. Saharawat, Y.S., Jat, H.S., Singh, M., Kumar, A., Jat, M.L., Humphreys, E., Sharma, D.K., Sharma, S. and Ladha, J.K. (2013). Optimizing intensive cereal-based cropping systems addressing current and future drivers of agricultural change in the northwestern Indo-Gangetic Plains of India. Agriculture, Ecosystems and Environment, 177: 85-97.

Gupta, R., Gopal, R., Jat, M.L., Jat, R.K., Sidhu, H.S., Minhas, P.S., Malik, R.K. (2010). Wheat productivity in indo-gangetic plains of India during 2010: Terminal heat effects and mitigation strategies. PACA Newsletter, 14:1-11.

Gupta, R.K. and Sayre K.D. (2007). Conservation agriculture in South Asia. Journal Agricultural Science, 145: $207-$ 214.

Hira, G. S. (2009). Water management in northern states and the food security of India. Journal Crop Improvement,
23: $136-157$

Jat, M.L. (2013). Green House Gases (GHGs) emission studies in contrasting rice establishment methods under ricewheat rotation of Indo-Gangetic plains of India. Annual Progress Report. Bayer Crop Science GHG project. International Maize and Wheat Improvement Centre (CIMMYT), El Batán,Texcoco, Edo. de Mexico, C.P. 56130 Mexico.

Jat, M.L., Gathala, M.K., Ladha, J.K., Saharawat, Y.S., Jat, A.S., Sharma, S.K., Kumar, V., Gupta, R.K. (2009). Evaluation of precision land leveling and double zerotillage systems in the rice-wheat rotation: Water use, productivity, profitability and soil physical properties. Soil Tillage Research, 105: 112-121.

Jat, M.L., Gathala, M.K., Saharawat, Y.S., Tetarwal, J.P., Gupta, R. and YadvinderSingh. (2013). Double no-till and permanent raised beds in maize-wheat rotation of north-western Indo-Gangetic plains of India: Effects on crop yields, water productivity, profitability and soil physical properties. Field Crops Research, 149: 291299.

Jat, M.L., Jat, R.K., Gupta, Raj, and Gopal, Ravi. (2011). Conservation agriculture in cereal systems of South Asia: effect on crop productivity and carbon-based sustainability index. In: Resilient food systems for a changing world, Proceedings of the 5th World Congress of Conservation Agriculture Incorporating 3rd Farming Systems Design Conference, Brisbane Australia, 26-29 September, 2011, p 26- 27.

Jat, M.L., Malik, R.K., Saharawat, Y.S., Gupta, Raj, Mal, B. and Paroda, Raj (Eds). (2012). Regional Dialogue on Conservation Agricultural in South Asia. Asia Pacific Association of Agricultural Research Institutions (APAARI), International Maize and Wheat Improvement Center (CIMMYT), Indian Council of Agricultural Research (ICAR), New Delhi, India. p 34.

Khuhro, G.A., Tunio, G.S., Maitlo, N. and Mari, N. (2002). Zerotillage sowing method of wheat followed by transplanted rice in Rice-wheat system. Journal of Applied Science, 2:302-307.

Ladha, J.K., Kumar, V., Alam, M.M., Sharma, S., Gathala, M., Chandna, P., Saharawat, Y.S. and Balasubramanian, V. (2009). Integrating crop and resource management technologies for enhanced productivity, profitability, and sustainability of the rice-wheat system in South Asia. In "Integrated Crop and Resource Management in the Rice-Wheat System of South Asia" (J. K. Ladha, Y. Singh, O. Erenstein, and B. Hardy, Eds.), International Rice Research Institute, Los Banõs, Philippines. pp. 69 108.

Malik, R.K., Gupta, R.K., Singh, C.M., Yadav, A., Brar, S.S., Thakur, T.C., Singh, S.S., Singh, A.K., Singh., R. and Sinha, R.K. (2005). Accelerating the Adoption of Resource Conservation Technologies in Rice Wheat System of the Indo-Gangetic Plains. Proceedings of Project Workshop, Directorate of Extension Education, Chaudhary Charan Singh Haryana Agricultural University (CCSHAU), June 1-2, 2005. Hisar, India.

Razzaq, A., Zafar, M.A. and Sabir, B.A. (1997). Control of insect pests on rice using tillage practices. Mechanizasion in Asia, Africa and Latin America, 28:29-30.

Saharawat, Y.S., Singh, B., Malik, R.K., Ladha, J.K., Gathala, M., Jat, M.L., Kumar, V. (2010). Evaluation of alternative tillage and crop establishment methods in a ricewheat rotation in north-western IGP. Field Crops 
Research, 116: 260-267

Singh, B. (2012). Incidence of the pink noctuid stem borer, Sesamia inferens (Walker), on wheat under two tillage conditions and three sowing dates in north-western plains of India. Journal of Entomology, 9(6): 368-376.

Singh, B., Shan, Y.H., Johnson-Beebout, S.E., Singh, Y. and Buresh, R.J. (2007). Crop residue management for lowland rice based cropping system in Asia. Advance in Agronomy, 98, 118-186.

Singh, H., Raheja, A., Sharma, R. and Kaur, T. (2013). Happy seeder - A conservation agriculture technology for managing rice residue for Central Punjab conditions. International Journal of Agricultural Engineering, 6 (2) : 355-358

Singh, Y. and Sidhu, H.S. (2014). Management of Cereal Crop Residues for Sustainable Rice-Wheat Production System in the Indo-Gangetic Plains of India. Proceedings Indian National Science Academy, 80 : 95-114

Tripathi, R.S., Raju,R. and Thimmappa, K. (2013). Impact of zero tillage on economics of wheat production in Haryana. Agricultural Economics Research Review, 26:101108. 